\title{
POLITYKA ENERGETYCZNA - ENERGY POLICY JOURNAL
}

$2021 \uparrow$ Volume $24 \uparrow$ Issue $3 \uparrow 141-160$

DOI: $10.33223 / \mathrm{epj} / 139232$

\section{Barriers and current challenges facing the renewable energy implementation in Libya: a review}

ABSTRACT: Given the importance of renewable energy as it provides alternative energy sources over the traditional fossil fuel that is environmentally friendly, clean and renewable, this research aims to explore scholarly articles and books that present and investigate the challenges and barriers facing the implementation of renewable energy sources in Libya where the social, cultural, financial and awareness aspects are an important consideration against renewable energy. This study contains a review of all relevant, peer-reviewed, and published articles from journals, websites, books, con-

$\triangle$ Corresponding Author: Mussa Mohamed Bahour; e-mail: mussa198754@gmail.com

${ }^{1}$ Business School, University Kuala Lumpur, Malaysia; ORCID iD: 0000-0003-3904-5305; e-mail: mussa198754@ gmail.com

2 Advance Facilities Engineering Technology Research Cluster (AFET-RC); Facilities Maintenance Engineering Section (FAME), Malaysian Institute of Industrial Technology, Universiti Kuala Lumpur (UniKL MITEC), Persiaran Sinaran Ilmu, Bandar Seri Alam, 81750, Johor, Malaysia; ORCID iD: 0000-0001-7652-8141; e-mail: munir@unikl. edu.my

3 Advance Facilities Engineering Technology Research Cluster (AFET-RC); Facilities Maintenance Engineering Section (FAME), Malaysian Institute of Industrial Technology, Universiti Kuala Lumpur (UniKL MITEC), Persiaran Sinaran Ilmu, Bandar Seri Alam, 81750, Johor, Malaysia; ORCID iD: 0000-0002-7905-1913; e-mail: mohdalfatihhi@ unikl.edu.my

${ }^{4}$ Advance Facilities Engineering Technology Research Cluster (AFET-RC); Facilities Maintenance Engineering Section (FAME), Malaysian Institute of Industrial Technology, Universiti Kuala Lumpur (UniKL MITEC), Persiaran Sinaran Ilmu, Bandar Seri Alam, 81750, Johor, Malaysia; ORCID iD: 0000-0001-5259-7775; e-mail: adnanb@unikl. edu.my permits use, distribution, and reproduction in any medium, provided that the Article is properly cited. 
ference proceedings and bulletins. An extensive literature review was carried out with the aim of researching renewable energy in Libya. This was done to take a realistic perspective of the community and the knowledge services accessible. The review of literature has shown that further renewables energy research remains necessary as the current conditions of the energy sector in Libya need to be examined to understand the challenges and difficulties to introduce renewable energy within competent authorities and businesses are examined in accordance with their managers. This indicates the need to conduct various studies in Libya to explore the various challenges, mostly financial and technological, that face the purposeful implementation of renewable energy resources in Libya. Additionally, the level of awareness and culture perception of the use of renewable energy is an important aspect to be considered as reported as barriers affecting the implementation of renewable energy in various parts of the world.

KEYWORD: alternative energy, implementation of renewable energy, barriers and challenges

\section{Introduction}

In order to maintain people's lifestyles, minimize greenhouse pollution, and slow down the degradation of energy resources, renewable energies are becoming increasingly necessary (Deigaard and Nielsen 2018). In the context of Libya, the application of renewable energy is not widely considered as a popular choice; thus, they are less studied due to the increased supply of both oil and natural gas. Libya is considered to be the world's largest exporter of both oil and natural gas and among countries to the world's most abundant reserves. To keep oil supplies for future generations and to reach the green energy sector and mitigate emissions, there is an opportunity for conservation and further growth of renewable energy resources (RER). There is widespread availability of green energy in Libya, such as solar and wind energy. (Nasar and Elzentani 2016) considers Libya to be the world's hub of in the case of renewable energy uses and implications due to solar energy potential and the vigorous wind movement intensity. Various sources of green resources must be explored and invested in to split Libya's reliance on a single source of revenue: oil (Nasar and Elzentani 2016).

The priorities of the development plans in Libya include providing enough electricity supply and connection to all the regions, which is driven by the reality that each individual's average electricity consumption is considered a fundamental measuring factor in modern societies' level of growth (Kassem et al. 2020).

The vast region the network has to serve, and the scale of infrastructure costs are, however, significant (Alweheshi et al. 2019). In agriculture and manufacturing, Libyan energy prices have drained the public expenditure over the last thirty years, as shown in the annual auditors' reports.

Most of the project related to electricity in Libya is being directed to the field of transportation. As a result, numerous projects relating to textiles, agriculture food, and fertilizers were abandoned owing to a spike in local production costs. The value of expenditure in green energy 
in the immediate future has also been seen in recent reports, for example, the Financial Audit Authority Study 2007 (GPCFAAL 2007), and the Ministry of Power, Water and Gas study 2008 (GPCEWGL 2008).

Geographical location and population.

Libya is a key country in the MENA region, occupying a strategic location in North Africa and serving as a link between Southern Europe and the rest of Africa. Even though Libya is considered as one of the oil-rich countries, it is vital to secure alternative resources of energy, especially as it has only one type of energy resources (oil). Growing alternative energy resources can, in turn, help to maintain oil resources for future generations, when the price of oil goes up, and to reduce current pollution.

Libya has the highest documented oil reserves and is one of the largest documented gas reserves in North Africa in its history. It is also a member of the Organization of Petroleum Exporting Countries (OPEC) (Bolesta 2018). Libya has a unique location in North Africa's center. It shares its borders with six countries around the Mediterranean Sea: Tunisia, Algeria, Niger, Chad, Sudan, Egypt (Badi et al. 2018; Capasso 2020). The sun is heavily exposed throughout the year and the coastal areas, plateaus and mountains comprise much of the surface of Libya.

The desert stretches into the south, with settlements and small towns dispersed across it. The atmosphere in the Mediterranean: the summer is warm, and the winter is mild. In summer, the desert atmosphere is scorching in the south, and diurnal temperature levels are extreme. The average temperature in winter is around $15^{\circ} \mathrm{C}$, and in summer, it is around $35^{\circ} \mathrm{C}$ (Blanchard 2016).

At present, the primary energy supply is oil. Oil is additionally considered as significant export revenues, which constitute 75 percent of Libya's income and is very significant for its economic growth (Komoto et al. 2009). Libya has a low population density, with a population of 5.6 million (CBL 2009), in a vast region of $1,759,540 \mathrm{~km}^{2}$ (Central Bank of Libya 2005), as estimated by the Central Bank of Libya.

Libya has a vast region and a low average population density, even though $90 \%$ of the people reside along the coast, which is less than $10 \%$ of the region. More than half of the people are metropolitan, mostly in Tripoli and Benghazi, two large cities (Otman and Karlberg 2007). The population in Libya consists of a mixture of Arab, Berber, and Toareq. In south Libya, the population is divided into two groups, mostly nomadic or semi-nomadic people are scattered in several areas. All are considered as native Libyan. In 1954, the first national census found that there were 1.041 million inhabitants, rising by 2006 to approximately 5.67 million (Central Bank of Libya 2005). The accuracy of the recent evaluations, particularly of organizations, can hardly be evaluated, though, the population continues to rise continuously.

The CIA reports that the population of Libya in 2012 was 6,733,620 (CIA 2016). The annual rate of natural growth in Libya is also one of the best in Africa (birth rate, lower death rates). Libya is also one of the 26 developed world countries with a population that could be projected to double in the next 25 years (Otman and Karlberg 2007). The current Libyan population is 6,871,292 (Worldometer 2020). 


\section{Libya's energy situation}

The energy supply of any country cannot be considered as indefinitely sustainable due to the fluctuating cost of energy, the limited resources and the environmental issue that may be accompanied with the use of specific energy sources (Khalil and Asheibe 2015). Libya is no exception, the conventional energy sources in Libya are oil and natural gas which are also considered as the primary source of income and revenue for the country (Mohamed et al. 2016). Libya possesses the largest oil reserves among African countries (Mohamed et al. 2019). Figure 2 shows the oil reserve in Libya, among other African countries. According to (U.S. Energy Information Ad-

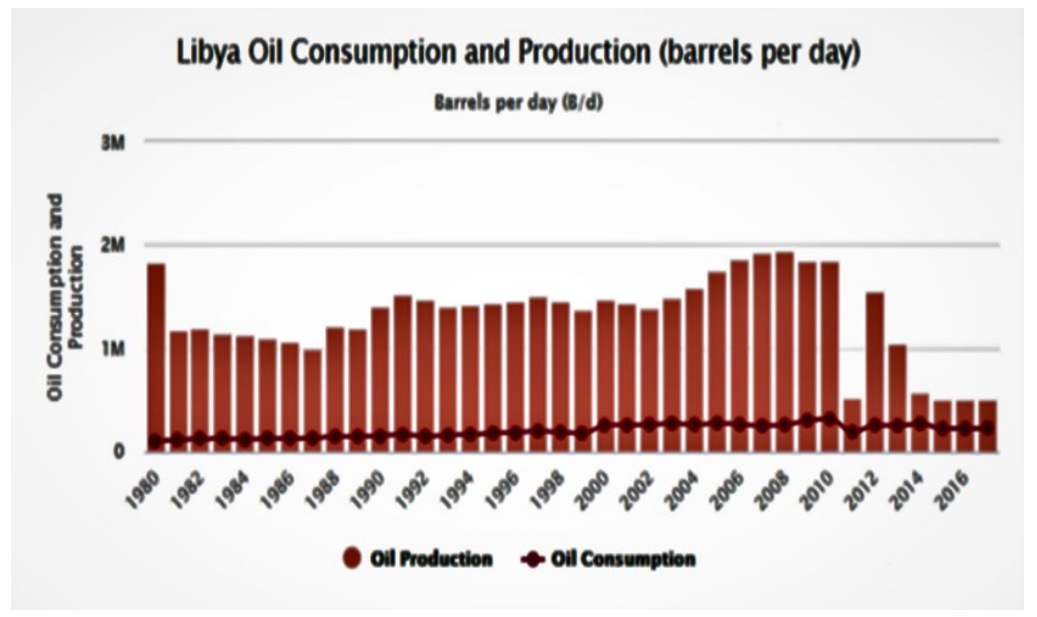

Fig. 1. Oil production and oil consumption in Libya from 1980-2016 (Worldometers 2016b)

Rys. 1. Produkcja ropy i jej zużycie w Libii w latach 1980-2016

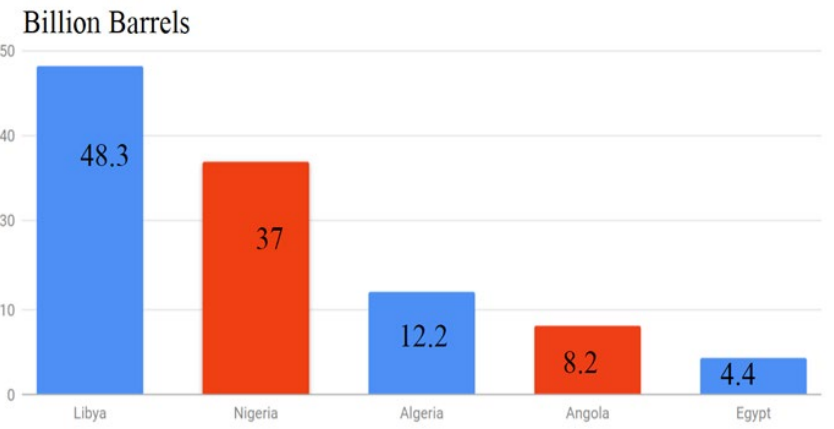

Fig. 2. Africa's top countries with oil reserves in billion barrels in 2016 (OPEC 2016)

Rys. 2. Kraje Afryki z największymi zasobami ropy naftowej w 2016 r. 


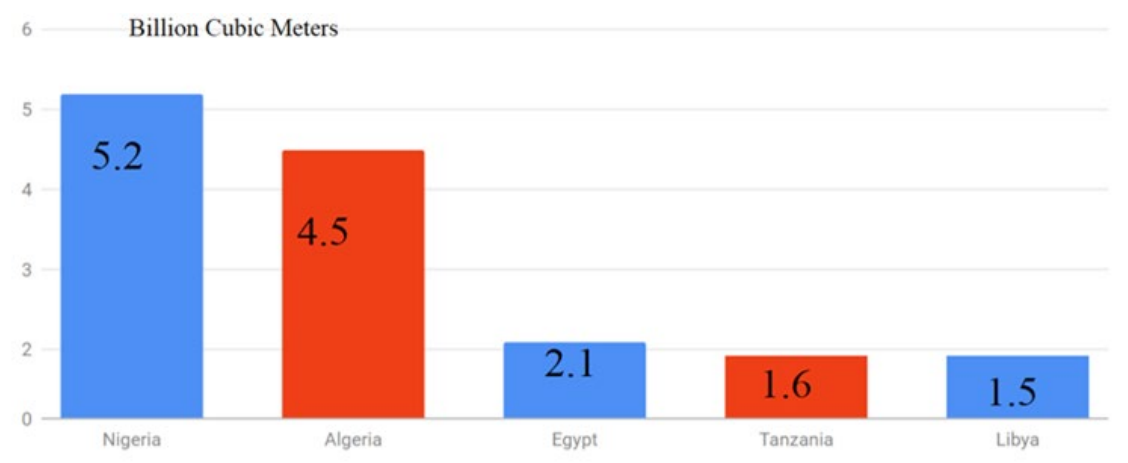

Fig. 3. Top African with natural gas reserves in Billion Cubic Meters 2016 (OPEC 2016)

Rys. 3. Kraje Afryki z największymi zasobami gazu ziemnego w 2016 r.

ministration 2019), Libya possesses around 48.3 billion barrels in reserve. The last data is from 2016 due to the political situation and conflict in Libya that limits the availability of accurate information.

Libya is considered the ninth country around the world in terms of oil reserves. The country only consumes 223,000 barrel per day, which is only $0.2 \%$ of world-consumption. According to (Worldometers 2016a), Libya exports $48 \%$ of its oil production as oil is the major revenue source for the country. Figure 1 demonstrates a comparison between oil production to oil consumption in Libya from 1980-2016. Since 2014 the country's oil production has reduced due to political conflict. The country continued to increase production as it reached around 1.2 million barrels of oil per day in 2019, which is considered a 100\% increase compared with production in 2016. However, the production in early 2020 dramatically decreased due to the increased intensity of the civil war in Libya. The production of the country is distributed with the current political and military conflict in the country (2020 Predictions for the Global Economy and Markets 2020).

The population in Libya is estimated as 6,492,162 people in 2016, and the country consumes 0.04 Barrels of oil per capita every which is estimated as (14 barrels) per capita per year (Worldometers 2016b).

Natural gas in Libya is also a significant source of energy. Libya possessed 53 trillion cubic feet of natural gas reserves in 2017. The country is situated as the 21 st country in the world in natural gas reserves. The natural gas consumption is estimated at 157,147 million cubic feet which are placed in the 60th position in the world and is considered as $0.1 \%$ of the total world consumption. According to (Worldometers 2016b), Libya consumes 65 cubic feet per capita per day. Figure 3 demonstrates the position of Libya among the fifth position among the African countries with natural gas reserves. Figure 4 demonstrates the natural gas production in comparison to consumption. The decrease in the gas production is noticed due to the country's political conflict.

According to (Ajredi et al. 2017), about $95 \%$ of Libyan revenues come from petroleum sales to various countries, the Libyan Ministry of Economy estimates that the continuous disruption 


\section{Libya Gas Consumption and Production (MMcf)}

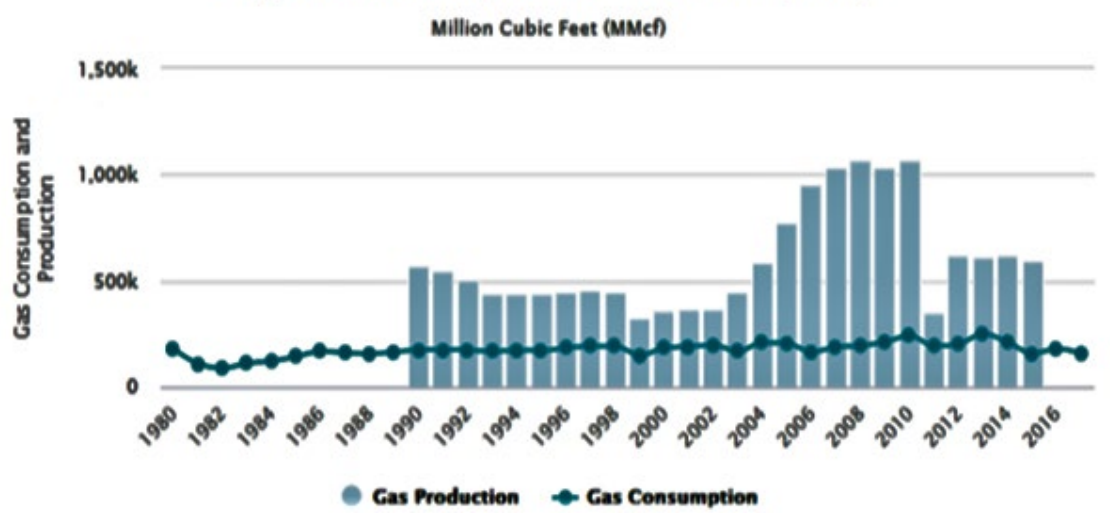

Fig. 4. Natural Gas production vs consumption in Libya (Worldometers 2016b)

Rys. 4. Produkcja i konsumpcja gazu ziemnego w Libii

cost over USD 10 billion or about 12\% of its GDP in 2013 (Ajredi et al. 2017). The Libyan economy is heavily dependent on oil and natural gas, which influence the country's adapting to renewable energy sources (Adan et al. 2018; Mohamed 2016).

Modernization increased energy demand in modern-day Libya. The energy sector is significant in economic and social development. The electricity demand increased due to the increase in industrialization and population. In 2014, Libya suffered many blackouts due to deficiency of a power plant that produces electricity. In Libya, electricity production and supply are the functions of the Global Electricity Company (GECOL) which is a state-owned company. To keep up with the electricity demand, new power plants needed to be built. Currently, most of the power plants are fueled by natural gas to free up more oil for exportation. Figure 5 shows that most of the energy supply in Libya still depends on heavy fuel oil (42\%), while

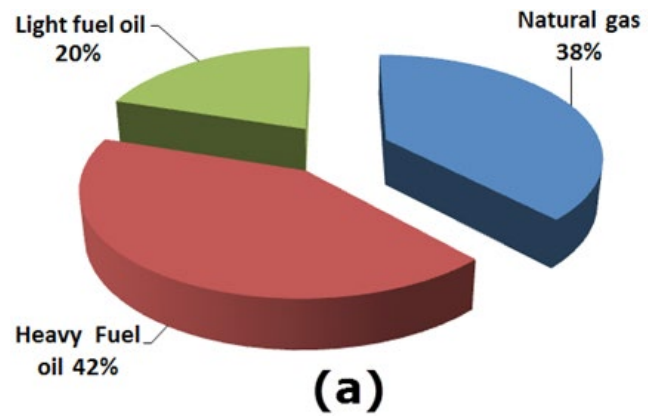

Fig. 5. Percentage of fuel used in electricity generation (Mohamed and Masood 2018)

Rys. 5. Procentowe udziały paliw w produkcji energii elektrycznej 
(38\%) of energy comes from natural gas, and (20\%) from light fuel oil. In terms of renewable energy resources, Libya does not depend on them to any degree (Mohamed 2016; Mohamed and Masood 2018).

\section{Knowledge and perception barriers}

The knowledge and awareness about the problem or issue is an essential factor in finding a solution for the implementation of specific strategies. The nature of the case of renewable energy requires a high level of awareness about the environmental impact of the use of conventional fossil energy resources for resources depletion to pollution of the environment. Another essential aspect of awareness is the general public perception towards renewable energy resources (Feron 2016; Patil 2018). The lack of technical information is reported as a barrier in the case of small biogas plants in Kenya that limit the adoption of these technologies among the farmers (Pueyo 2018). Similar barriers are reported in the United Kingdom, where there is a lack of exchange information about the innovation systems for renewable energy technologies (Nengroo et al. 2018). The perceived financial risk of investment is reported in the literature in developing countries as the renewable energy technologies are expensive and not easily used, the low quality and effectiveness are also seen as knowledge barriers (Mercer 2016). Renewable energy technologies are generally perceived as inferior technologies in the relation of user comfort and utility. The failed experience of renewable energy technologies is always present in the public perception of the technology, an example is from the wind parks in the Dodecanese Islands of Greece and the failed biogas plants in Kenya (Paravantis et al. 2018). Other projects in India are also perceived as a failure to enhance the standard of living (Martinez-Manuel 2021). In Libya, there are no current or previous active projects that can be used an example of success or failure in dealing with renewable technologies as the country has zero percent of the source of power from renewable energy sources (Mohamed et al. 2019; Mohamed and Masood 2018).

\section{Technical barriers}

The technological barriers discussed in the literature in relation to the implementation of renewable energy resources involves three significant aspects related to the availability of technological resources, the availability of technology and the skills attributes. According to (Luthra et al. 2015), the technological barrier is considered as the most reported barrier that hinders the implementation of different renewable energy system structures, especially in the decentralized 
networks (Luthra et al. 2015; Reddy and Painuly 2004). In the following section, we describe the literature available on the various attributes related to technological barriers.

\subsection{Renewable energy resource availability}

The availability of the natural resources of renewable energy is discussed in the literature under the technical barrier. In many countries, the available renewable resources are not the same, and they are subjected to fluctuation, inadequacy, and intermittency. The most discussed natural resource of renewable energy is wind, solar, hydropower and biomass. The availability of these resources are cited in (Herbert and Krishnan 2016; Ahadzie et al. 2009) as a technological barrier.

The notion can be further clarified through examples. Based on a research done by (Khojastehet al. 2016) in India, the decreased availability of resources hindered the completion of important projects such as s solar cooker, solar photovoltaic lantern, domestic solar water-heater and family-type biogas plant. Another example is a study from Turkey, which indicated that the limitation on solar resources obstructed the implementation of solar water heaters (Doğanalp 2018). Wind seasonal fluctuation in Greece limited the use of wind installations on the Dodecanese islands (Paravantis et al. 2018).

\subsection{Human resources availability}

The need for skills that perform manufacturing, operation, installation and maintenance of the renewable energy fields and plants are essential in the successful implementation of these technologies and reaching full potential capacity. There is the general shortage of human resources that are familiar with renewable energy technologies as mentioned in many (Al-Hamamre et al. 2017; Doğanalp 2018).

According to (Doğanalp 2018), the lack of workers experienced in renewable energy decentralized network structures hindered the widespread implementation in ASEAN countries and Turkey (Doğanalp 2018). In the MENA region, according to (Al-Hamamre et al. 2017; Khalifa et al. 2019), there are no local manufacturers of renewable technologies (RT) which acts as a huge barrier, especially in developing countries. In Kenya, solar buildings require foreign designs which lead to the decreased reliability of the technology and decrease the chance of wide-spread application (Pueyo 2018). 


\subsection{Technology performance level, design and installation}

In terms of performance, renewable energy sources provide less power in comparison to traditional fossil fuels as they tend to have less energy output per unit floor areas (Luthra et al. 2015). The design and installation of various renewable energy plans require technologies and human resources skills that add a technological barrier. These barriers were discussed in numerous articles such as (Shibin et al. 2016). Low efficiency has been reported with solar dryers in India (Tomar et al. 2017).

The complex design required for renewable energy plants is also a considerable barrier that limits the widespread implementation of these technologies. Many articles reported issues related to the complexity of the design in countries such as India, Tanzania and the US (Atadashi et al. 2012). Other studies such as (Shibin et al. 2016) revealed issues related to the maintenance and repair of both biomass and solar panels in India and Nepal.

\subsection{Reliability and standardization}

Reliability and a lack of standardization leading to system failures are one of the main reasons unpromising of its mass adoption of Decentralized energy systems. The lack of standardization, poor quality and low reliability was reported in (Sindhu et al. 2016; Collotta et al. 2018; Suman and Ahamad 2018).

The previously mentioned aspects of inconsistent availability, the lack of skilled human resources to operate, install and maintain renewable technology, low-performance level, low efficacy in comparison to fossil fuel, along with the complexity of the design, the lack of standardization and low quality and reliability all contribute to technological barriers which are in less favor of the widespread implementation of renewable energy technologies of different energy sources like wind, solar, hydropower and biomass.

\section{Economic barriers}

The economic and the financial issue associated with the adoption of new renewable energy technologies are among the most essential aspect that is considered as barriers for the widespread implementation of the technology (Murshed 2020). In literature, the barrier is discussed among many aspects including, high initial capital cost, long payback period, the price difference in favor of conventional fossil fuels, high transaction costs of renewable energy projects, lack of private sector investments (Strantzali and Aravossis 2016). In the following section, 
we explore the various financial and economic barriers in various countries, as discussed in the literature.

\subsection{The high initial capital cost of technology}

The issue of the high initial cost for the implementation of renewable energy technology is reported by many researchers as a significant economic barrier. The high cost is not always related to the technologies or devices used. This can also be seen in administrative procedures such as the required (Luthra et al. 2015). Regardless of the source of renewable energy used and regardless the country, the high cost is always a barrier as renewable energy is set in comparison to other conventional energy sources ranging from traditional self-made ovens in India where the source of power is wood for the fire, or the conventional fossil fuel water heaters or electric heaters. The following section will explore the example of renewable technologies in various countries and the influence of the high cost on their adoption.

In Bangladesh, a company called Grameen Shakti reported that the high cost of the solar PV module is a significant barrier in the country that prevents the implementation of photovoltaic systems despite the presence of sufficient solar energy sources (Luthra et al. 2015). In Thailand and Nigeria, the use of photovoltaic battery charging stations reported a high cost of operation and maintenance, especially in small villages (Suzuki et al. 2010; Abdullahi et al. 2017). The renewable energy projects are usually small in size, service and have a limited area (in most of the cases, small villages, and islands where centralized energy network is not easily achieved). The small projects will have a higher cost. In most of the cases, the individuals or families are required to bear the cost of the renewable energy network installation, operation and maintenance (Armaroli and Balzani 2007; Ansari et al. 2013).

\subsection{Users' purchasing power}

The renewable energy power, especially the decentralized networks, is often perceived as an individual solution by families or local authorities. The individuals do not have the economic abilities of general authorities. It is expected that the purchasing power of users will significantly influence the adoption of renewable energy solutions such as the use of biogas or the use of solar energy-based cooking systems (Suzuki et al. 2010). In developing countries such as Bangladesh and India especially in rural areas, poverty leads to low purchasing power which is considered as a barrier that prevents the use of solar systems (Sharma and Thakur 2017). In Greece, the use of a solar domestic hot water system is greatly affected by spending priorities users (Paravantis et al. 2018). 


\subsection{Renewable energy market}

In general, the energy market has a significant influence on the adoption and implementation of renewable energy technologies. The current market structure is designed for conventional energy with high biased against renewable energy technologies (Luthra et al. 2015). In most of the cases, the countries general authority such as the General Electric company of Libya, or Holding companies where the government authority makes the voting power and decisions enables each country to favor the conventional energy sources as most of the power plant, and sparse distribution networks are already built to support conventional energy. This leads to policies, regulations and trade barriers discouraging the implementation of renewable energy. Another example is from Thailand, as the energy-related enterprises are state-owned, and they create market barriers against private renewable energy companies (Etelawi et al. 2017; Mohamed et al. 2019; Mohamed and Masood 2018). Similar barriers are reported in India (Sharma and Thakur 2017).

\subsection{Tax and tariff}

In some cases where governments support and encourage the use of renewable energy sources, they will offer a capital subsidy, carbon credit, soft loan, reduction or waiver of taxes and any other form of financial encouragement (Luthra et al. 2015). However, as discussed in the previous section, most of the significant power suppliers are government entities which receive full government and authority support in comparison to private companies that promote renewable energy resources. The majority of conventional energy generation technologies receive many benefits, such as tax exemption and tariff support (Luthra et al. 2015). This leads to a lack of encouragement that promotes the adoption of renewable energy. A similar condition is repeated in many countries, such as Greece, Australia, India and Thailand (Trutnevyte et al. 2016; Paravantis et al. 2018). These factors limit the adoption and widespread use of renewable energy technologies. According to (Khare et al. 2013), tax barriers and tariff policies on imported equipment favor the use of conventional energy sources over renewable energy technologies (Khare et al. 2013).

\section{Policies and regulations barriers}

There are global policies that control and moderate fossil fuels and nuclear energy (Herington et al. 2017; van Horne and Dutot 2017). In general, renewable energy resources lacks regulatory 
policies and a framework which acts a barrier as discussed in many publications (Kumar and Katoch 2014; He et al. 2018). These barriers can be categorically divided into policy, regulation, and administrative barriers.

\subsection{Administrative barriers}

The bureaucratic procedure is often associated with the implementation of renewable energy technology. In many countries, coordination among various authorities is required for the effective implementation of renewable energy resources (Reddy and Painuly 2004; Piwowar and Dzikuć 2019). In Bangladesh, coordination is required between various ministries and agencies as the budget for renewable energy plants, and fields construction depend on the national budget (Khan et al. 2018). In China, inadequate monitoring and evaluation from the authorities lead to the failure of large scale biomass cook stoves implementation (Mirkouei et al. 2017; IM Atadashi et al. 2012). Similar results are reported from India as a lack of adequate monitoring, evaluation and funding lead to the failure of many programs (Solangi et al. 2019).

\section{Social barriers}

The conversion from conventional energy resources to renewable energy is faced by a certain degree of public resistance and opposition. This has contributed to many factors such as the lack of awareness regarding the environmental impact of conventional fossil fuel, the lack of awareness on the benefits and potential of renewable energy, the general public perception of low efficiency and quality of renewable energy, public perception towards the high cost of renewable energy technologies and disruption of a seascape (Feron 2016; Seetharaman et al. 2019). In many countries, renewable energy projects face opposition due to various reasons depends on the cause and nature of the project, to provide examples, the installation of wind energy fields in Turkey is opposed due to weak social compatibility (Doğanalp 2018). In Greece, the preservation of natural resources and cultural heritage was the reason behind the opposition of wind energy projects (Paravantis et al. 2018). Conservative rural traditions and psychological barriers were reported to oppose the implementation of renewable energy projects in rural areas of India. In the US, psychological attributes such as freedom, comfort, trust, control, and social status are opposed to the widespread implementation of renewable energy projects in the country (Luthra et al. 2015). 


\section{The successful European experience of switching to renewable energy}

According to (Renewable energy statistics 2020) since 2009, the European Union (EU) has set an explicit objective for the share of renewable energy (RE) in gross final energy consumption. This was decided in the under the context of the "European Union (EU) climate and energy package" (the so-called 20-year plan), a 20\% decrease in EU greenhouse-gas (GHG) emissions from 1990, and a 20\% RE share in the European Union (EU) final energy consumption (including a 10\% renewable share in the transport sector). The European Union's energy efficiency is improving. The RE objective has been met to give mandated national objectives that vary by country Member States, considering their various starting places in terms of in terms of energy mix, renewable energy potential, GDP, and past efforts. Reducing anthropogenic greenhouse gas (GHG) emissions in order to combat climate change is a serious problem for humankind in the twenty-first century (UNFCCC 2020). Climate change and global warming are anticipated to result in more extreme weather occurrences, crop failures, and increasing sea levels, all of which inflict significant damage and financial loss. Annual GHG emissions have been gradually growing since the beginning of industrialization in the 19th century, with no sign of a stopping point in sight (Le Quéré et al. 2017; Jolly et al. 2015). The generation of heat and electricity accounts for $25 \%$ of all GHG emissions (Suckling and Frasier 2015). At the 2015 United Nations Climate Change Conference (COP 21) in Paris, 195 UNFCCC participating member states and the European Union decided to further up their mitigation efforts to address the challenge of human-caused climate change (UNFCCC 2020). The European Union (EU) proposed a significant reduction of objectives as part of its response: as part of the efforts needed of industrialized nations as a bloc, the EU targets to reduce emissions by 80 to 95 percent by 2050 compared to 1990 levels (UNFCCC 2020). The power production industry has the strictest emission objectives, ranging from 93 to 99 percent below 1990 levels. The European Union (EU) has pledged to decarbonizing Europe's electrical supply system by setting these goals (Bussar et al. 2014). As a result, nations that did not initiate the notion of transitioning to renewable energy, such as Libya, should learn from the experience of nations that came before them in this sector, such as the European Union.

\section{Conclusion}

Libya is considered as the ninth country around the world in terms of oil reserves. Libya exports $48 \%$ of its oil production as oil is the primary revenue source for the country. The natural gas in Libya is also an essential source of energy, Libya possessed 53 trillion cubic feet of natural gas reserves in 2017. Modernization increased energy demand in modern-day Libya. The ener- 
gy sector is significant in economic and social development. The electricity demand increased due to the increase in industrialization and population. In 2014, Libya suffered many blackouts due to the deficiency of a power plant that produces electricity. The country aims to implement renewable energy sources. There are little details in the literature about the specific barriers that hinder the adoption of renewable energy in Libya.

The technological barriers discussed in the literature in relation to the implementation of renewable energy resources involves three significant aspects related to the availability of technological resources, the availability of technology and the skills attributes. The economic and the financial issue associated with the adoption of new renewable energy technology are among the most essential aspect that is considered as barriers for widespread implementation of the technology. In literature, the barrier is discussed among many aspects including, high initial capital cost, long payback period, the price difference in favor of conventional fossil fuels, high transaction costs of renewable energy projects, and the lack of private sector investments.

Renewable energy technologies face regulatory barriers hindering their implementation. Many barriers are reported in the literature as the lack of agencies to allocate information; lack of organization among several agencies undefined management policies; the lack of a legal monitoring framework; lengthy bureaucratic procedures; unstable macro-economic environment; lack of research and development; and absence of private sector participation.

The conversion from conventional energy resources to renewable energy is faced by a certain degree of public resistance and opposition. This has contributed to many factors such as the lack of awareness regarding the environmental impact of conventional fossil fuel, the lack of awareness on the benefits and potential of renewable energy, the public perception of low efficiency and the quality of renewable energy, public perception towards the high cost of renewable energy technologies.

Libya is one of the nations that heavily supports the energy sector. The cost of energy in Libya is USD 0.004 per kWh for homes and USD 0.007 for enterprises, which includes all components of the energy bill such as power costs, distribution costs, and taxes. In comparison, the global average price of power during that time is USD 0.139 per kWh for homes and USD 0.125 for enterprises, which has had a detrimental impact on people's encouragement of the transition to renewable energy since people worry more about their monthly electricity cost than environmental concerns. Even after the 2011 political transition, the new governments are still following the same trajectory, especially with the civil war, ageing and decaying infrastructure, and political insecurity, there was no possibility for consecutive governments or competent authorities to develop a genuine project to move to renewable energy. And now, with recent events on the Libyan scene and the assistance of the UN, which aspires to set the December 2021 elections and solve the crisis of internal political conflict, the next administration chosen by the people must implement a serious project or plan for renewable energy transition. This policy entails elevating the government's hand and allowing the private sector, both domestic and international, to continue to flourish in this area, as in Libya's oil industry. and the government's role is limited to follow-up, as well as supporting the Scientific Research Centers and emphasizing the risks of environmental from traditional energy sources such as oil, coal, gas, etc. The clarification of the 
benefits of renewable energy on the environment, and the role of commercial banks in providing long-term loans funded by the government without interest to those who want to install a renewable energy system. Subsidies on traditional energy sources should be eliminated, and taxes on consumers should be added. Libya is part of a global system that must accept responsibility for environmental preservation and pollution reduction to ensure a better future.

\section{References}

2020 Predictions for the Global Economy and Markets 2020. [Online] https://www.investopedia. com/2020-predictions-for-the-global-economy-markets-and-investors-4780156 [Accessed: 2020-10-23].

ABDullahi, D. et al. 2017. Solar Energy Development and Implementation in Nigeria: Drivers and Barriers. DOI: $10.18086 /$ swc.2017.16.01.

Adan H. et al. 2018 - Adan, H., Fuerst, F., Kavarnou, D. and Singh, R. 2018. Me or my house? Investigating the relative importance of household and dwelling characteristics for household energy consumption. [Online] https://papers.ssrn.com/sol3/papers.cfm?abstract_id=3254320 [Accessed: 202006-24].

AHADZIE, D.K. et al. 2009. Towards developing competency-based measures for project managers in mass house building projects in developing countries. Construction Management and Economics 27(1), pp. 89-102, DOI: 10.1080/01446190802621028.

Ajredi et al. 2017 - Ajredi, M.A.S., Ayedh, A.M.A. and Haron, M.S. 2017. The Relationship between Real Exchange Rate and Components of the Broader Measure of Money Supply: An Analytical Study on the Libyan Economy. Journal of Insurance and Financial Management 3(3).

Al-HamamRe, Z. et al. 2017. Wastes and biomass materials as sustainable-renewable energy resources for Jordan. Renewable and Sustainable Energy Reviews. Elsevier, 67, pp. 295-314.

AlweHESHI, S. et al. 2019. Photovoltaic solar energy applications in Libya: a survey'. The $10^{\text {th }}$ International Renewable Energy Congress (IREC), pp. 1-6, DOI: 10.1109/IREC.2019.8754527. [Online] https:// www.researchgate.net/scientific-contributions/Shoroug-Alweheshi-2155953241 [Accessed: 2020-1205].

ANSARI, M.F. et al. 2013. Analysis of barriers to implement solar power installations in India using interpretive structural modeling technique. Renewable and sustainable energy reviews 27, pp. 163-174.

Armaroli, N. and Balzani, V. 2007. The future of energy supply: challenges and opportunities. Angewandte Chemie International Edition 46(1-2), pp. 52-66.

Atadashi et al. 2012 - Atadashi, I.M., Aroua, M.K., Abdul Aziz, A.R. and Sulaiman, N.M.N. 2012. The effects of catalysts in biodiesel production: A review. Journal of Industrial and Engineering Chemistry 19(1), pp. 14-26, DOI: 10.1016/j.jiec.2012.07.009.

BADI, I.A. et al. 2018. A grey-based assessment approach to the site selection of a desalination plant in Libya. Grey Systems: Theory and Application, DOI: 10.1108/GS-01-2018-0002.

BLANCHARD, C.M. 2016. Libya: Transition and US policy. Washington United States: Congressional Research Service. [Online] https://sgp.fas.org/crs/row/RL33142.pdf [Accessed: 2020-09-22].

BolestA, A. 2018. Myanmar-China peculiar relationship: Trade, investment and the model of development. Journal of International Studies 11(2), pp. 23-36.

Bussar, C. et al. 2014. Optimal allocation and capacity of energy storage systems in a future European power system with 100\% renewable energy generation. Energy Procedia 46, pp. 40-47, DOI: 10.1016/j. egypro.2014.01.156. 
CAPASso, M. 2020. The war and the economy: the gradual destruction of Libya. Review of African Political Economy 47, pp. 1-23.

CBL 2009. Economic Bulletin for the Fourth Quarter of 2009. Tripoli, Libya.

Central Bank of Libya 2005. [Online] https://cbl.gov.ly/en/ [Accessed: 2021-02-20].

CIA 2016. Central Intelligence Agency-The World Factbook.

Collotta, M. et al. 2018. Wastewater and waste $\mathrm{CO}_{2}$ for sustainable biofuels from microalgae. Algal research 29, pp. 12-21.

DeigaARD, R. and Nielsen, P. 2018. Wind generation of waves: Energy and momentum transfer - An overview with physical discussion. Coastal Engineering 139, pp. 36-46.

DoĞANALP, N. 2018. The nexus between renewable energy and sustainable development: a panel data analysis for selected eu countries. Journal of Social And Humanities Sciences Research (JSHSR) 5(29), pp. 3966-3973, DOI: 10.26450/jshsr.884.

Etelawi et al. 2017 - Etelawi, A.M., Blatner, K.A. and McCluskey, J. 2017. Crude Oil and the Libyan Economy. International Journal of Economics and Finance 9(4), pp. 95-104.

FERON, S. 2016. Sustainability of off-grid photovoltaic systems for rural electrification in developing countries: A review. Sustainability 8(12), pp. 1-26, DOI: 10.3390/su8121326.

GPCEWGL 2008. The Libyan General people's Committee for Electricity, Water and Gas. Annual Report. Tripoli - Libya.

GPCFAAL 2007. The General People's Committee of The Financial Audit Authority. Tripoli - Libya.

HE, Z.X. et al. 2018. Factors that influence renewable energy technological innovation in China: A dynamic panel approach. Sustainability 10(1), DOI: 10.3390/su10010124.

Herbert, G.M.J. and Krishnan, A.U. 2016. Quantifying environmental performance of biomass energy. Renewable and Sustainable Energy Reviews 59, pp. 292-308.

Herington, M.J. et al. 2017. Rural energy planning remains out-of-step with contemporary paradigms of energy access and development. Renewable and Sustainable Energy Reviews 67, pp. 1412-1419.

Van Horne, C. and Dutot, V. 2017. Challenges in technology transfer: an actor perspective in a quadruple helix environment. The Journal of Technology Transfer 42(2), pp. 285-301.

JoLLY, W.M. et al. 2015. Climate-induced variations in global wildfire danger from 1979 to 2013. Nature Communications. Nature Publishing Group, 6(May), pp. 1-11, DOI: 10.1038/ncomms8537.

Kassem et al. 2020 - Kassem, Y., ÇAmur, H. and Aateg, R.A.F. 2020. Exploring Solar and Wind Energy as a Power Generation Source for Solving the Electricity Crisis in Libyax. Energies 13(14), p. 3708 .

Khalifa et al. 2019 - Khalifa, R., DABAB, M. and BARHAM, H. 2019. A preliminary strategic framework for enhancing the sustainability of international technology transfer: The case of Libya. PICMET 2019 Portland International Conference on Management of Engineering and Technology: Technology Management in the World of Intelligent Systems, Proceedings, 1-9, DOI: 10.23919/PICMET.2019.8893662.

Khalil, A. and Asheibe, A. 2015. The chances and challenges for renewable energy in Libya. The Proceedings of the Renewable Energy Conference (November 2015), pp. 1-6.

KHAN, K.A. et al. 2018. Renewable energy scenario in Bangladesh. IJARII 4(5), pp. 270-279.

Khare et al. 2013 - Khare, V., Nema, S. and Baredar, P. 2013. Status of solar wind renewable energy. Renewable and Sustainable Energy Reviews 27(1), pp. 1-10.

Khare et al. 2017 - Khare, Vikas, Nema, S. and Baredar, P. 2013. Status of solar wind renewable energy in India. Renewable and Sustainable Energy Reviews 27, pp. 1-10, DOI: 10.1016/j.rser.2013.06.018.

Khojasteh et al. 2016 - Кноjasteh, D., Кноjasteh, D. and Kamali, R. 2016. Wave Energy Absorption by Heaving Point Absorbers at Caspian Sea. $24^{\text {th }}$ Annual International Conference on Mechanical Engineering-ISME. Yazd, Iran (April). 
Комото, K. et al. 2009. Energy from the desert: Very Large scale photovoltaic systems: Socio-economic, financial, technical and environmental aspects. Energy from the Desert: Very Large Scale Photovoltaic Systems: Socio-economic, Financial, Technical and Environmental Aspects, pp. 1-190, DOI: $10.4324 / 9781849770064$

KumaR, D. and KaTOCH, S.S. 2014. Sustainability indicators for run of the river (RoR) hydropower projects in hydro rich regions of India. Renewable and Sustainable Energy Reviews 35, pp. 101-108.

LuthrA, S. et al. 2015. Barriers to renewable/sustainable energy technologies adoption: Indian perspective. Renewable and sustainable energy reviews 41, pp. 762-776.

Martinez-Manuel, L. 2021. Flux solar simulator for the development of thesis that to obtain the degree of doctor of Science (optics) Presents: Leopoldo Martínez-Manuel (April).

MERCER, N. 2016. Barriers to renewable energy development in newfoundland and labrador: a case study of wind energy applying the 'aktesp' framework for analysis.

Mirkouei, A. et al. 2017. A mixed biomass-based energy supply chain for enhancing economic and environmental sustainability benefits: A multi-criteria decision making framework. Applied Energy 206(May), pp. 1088-1101, DOI: 10.1016/j.apenergy.2017.09.001

MoHAmed, A.M.A. 2016. Investigation into the feasibility of the utilisation of renewable energy resources in Libya (Doctoral dissertation, Nottingham Trent University).

Mohamed et al. 2019 - Mohamed, A.M.A., Elabar, S.M., Shakmak, B.H.M. and Al-Habaibeh, A. 2019 Exploring the sustainable economy and energy for Libya's future. Nottingham Trent University: Publications. [Online] http://irep.ntu.ac.uk/id/eprint/29037/ [Accessed: 2021-03-05].

Mohamed et al. 2017 - Mohamed, A.M.A., Al-Habaibeh, A. and Abdo, H. 2016. Future prospects of the renewable energy sector in Libya. Conference: Sustainable Built Environment. [In:] SBE16 Dubai Conference, Dubai, United Arab Emirates.

Mohamed, O.A. and Masood, S.H. 2018. A brief overview of solar and wind energy in Libya: Current trends and the future development. [In:] IOP Conference Series: Materials Science and Engineering 377(1), DOI: 10.1088/1757-899X/377/1/012136.

Murshed, M. 2020. Are Trade Liberalization policies aligned with Renewable Energy Transition in low and middle income countries? An Instrumental Variable approach. Renewable Energy 151, pp. 1110 -1123, DOI: 10.1016/j.renene.2019.11.106.

Nasar, M. and Elzentani, H. 2016. Smart Roads to Generate Energy in Libya: Survey. Environment \& Ecology 34(3A), pp. 1088-1092.

Nengroo et al. 2018 - Nengro, S.H., Kamran, N.A., Ali, M.U., Kim, D.-H., Kim, M.-S., Hussain, A. and KIM, H.-J. 2018. Dual battery storage system: An optimized strategy for the utilization of renewable photovoltaic energy in the United Kingdom. Electronics 7(9), p. 177.

OPEC 2016. [Online] https://www.opec.org/opec_web/en/search.jsp? [Accessed: 2020-06-27].

OtMAN, W. and KARLBERG, E. 2007. The Libyan economy: economic diversification and international repositioning. Springer Science \& Business Media, DOI: 10.1007/3-540-46463-8.

Paravantis et al. 2018 - Paravantis, J., Mihalakakou, G., Stigka, E. and Evanthie, M. 2018. Social acceptance of renewable energy projects: A contingent valuation investigation in Western Greece. Renewable Energy 123, pp. 639-651.

PATIL, D. 2018. Sustainable Bio-Energy Through Bagasse Co-Generation Technology: a Pestel Analysis of Sugar Hub of India, Solapur. Journal of Emerging Technologies and Innovative Research 5(12), pp. 661-669.

Piwowar, A. and Dzikuć, M. 2019. Development of renewable energy sources in the context of threats resulting from low-altitude emissions in Rural Areas in Poland: A review. Energies 12(18), DOI: 10.3390/ en12183558. 
Pueyo, A. 2018. What constrains renewable energy investment in Sub-Saharan Africa? A comparison of Kenya and Ghana. World Development 109, pp. 85-100.

Le QuÉRÉ, C. et al. 2017. Global_Carbon_Budget. Earth System Science Data (November).

Reddy, S. and Painuly, J.P. 2004. Diffusion of renewable energy technologies - barriers and stakeholders' perspectives. Renewable Energy 29(9), pp. 1431-1447.

Renewable energy statistics 2020. On-line: https://ec.europa.eu/eurostat/statistics-explained/index.php?title =Renewable_energy_statistics.

Seetharaman et al. 2019 - Seetharaman, A., Krishna Moorthy, M. and Nitin, P. 2019. Breaking barriers in deployment of renewable energy. Heliyon. Elsevier Ltd. 5(1), DOI: 10.1016/j.heliyon.2019.e01166.

Sharma, A.K. and ThakUR, N.S. 2017. Energy situation, current status and resource potential of run of the river (RoR) large hydro power projects in Jammu and Kashmir: India. Renewable and Sustainable Energy Reviews 78, pp. 233-251.

Shibin et al. 2016 - Shibin, K.T., Gunasekaran, A., Papadopoulos, T., Dubey, R., Singh, M. and Fosso WAMBA, S. 2016. Enablers and barriers of flexible green supply chain management: A total interpretive structural modeling approach. Global Journal of Flexible Systems Management 17(2), pp. 171-188.

Sindhu et al. 2016 - Sindhu, S., Nehra, V. and Luthra, S. 2016. Identification and analysis of barriers in implementation of solar energy in Indian rural sector using integrated ISM and fuzzy MICMAC approach. Renewable and Sustainable Energy Reviews 62, pp. 70-88.

Solangi et al. 2019 - Solangi, Y.A., TAN, Q., Mirjat, N.H., Valasai, G.D., Khan, M.W.A. and Ikram, M. 2019. An integrated Delphi-AHP and fuzzy TOPSIS approach toward ranking and selection of renewable energy resources in Pakistan. Processes 7(2), pp. 1-31, DOI: 10.3390/pr7020118.

Strantzali, E. and Aravossis, K. 2016. Decision making in renewable energy investments: A review. Renewable and Sustainable Energy Reviews 55, pp. 885-898, DOI: 10.1016/j.rser.2015.11.021.

SuCKLING, J.H. and Frasier, J.T. 2015. Adoption of the paris agreement. Experimental Mechanics 8(11), pp. 513-519, DOI: 10.1007/BF02327128.

Suman, S.K. and Ahamad, J. 2018. Solar energy potential and future energy of India: an overview. International Journal of Engineering Science, p. 17575.

SuZuKi et al. 2010 - SuZuKI, M., KeHDY, B.O. and JAIN, S. 2010. Identifying barriers for the implementation and the operation of biogas power generation projects in Southeast Asia: An analysis of clean development mechanism projects in Thailand. Economics and Management Series Working Paper, EMS-2010-20, International University of Japan, Japan.

Tomar et al. 2017 - Tomar, V., Tiwari, G. and Norton, B. 2017. Solar dryers for tropical food preservation: Thermophysics of crops, systems and components. Solar Energy 154, pp. 2-13.

TRUTNEVYTE, E. et al. 2016. Energy scenario choices: Insights from a retrospective review of UK energy futures. Renewable and Sustainable Energy Reviews 55, pp. 326-337, DOI: 10.1016/j.rser.2015.10.067.

UNFCCC 2020. [Online] https://unfccc.int/climate-action/introduction-climate-action [Accessed: 2020$-12-08]$.

U.S. Energy Information Administration 2019. [Online] https://www.eia.gov/ [Accessed: 2020-12-08]

Worldometers 2016a. [Online] https://www.worldometers.info/oil/libya-oil/ [Accessed: 2020-12-08].

Worldometers 2016b. [Online] https://www.worldometers.info/gas/ [Accessed: 2020-12-08].

Worldometer 2020. Libya Population. [Online] https://www.worldometers.info/world-population/libya-population/ [Accessed: 2020-12-08]. 


\title{
Bariery i wyzwania stojące przed wdrożeniem energii odnawialnej w Libii: przegląd
}

\begin{abstract}
Streszczenie
Biorąc pod uwagę znaczenie energii odnawialnej, zapewniającej alternatywną energię w stosunku do tradycyjnych paliw kopalnych, która jest przyjazna dla środowiska, czysta i odnawialna, niniejsze badanie ma na celu przegląd artykułów naukowych i książek, które przedstawiają i badają wyzwania i bariery stojące przed wdrożeniem odnawialnych źródeł energii w Libii, gdzie aspekty społeczne, kulturowe, finansowe i świadomościowe są ważnymi czynnikami, które nie sprzyjają energii odnawialnej. Niniejszy artykuł obejmuje przegląd wszystkich istotnych, recenzowanych i opublikowanych artykułów z czasopism, stron internetowych, książek, materiałów konferencyjnych i biuletynów. Obszerny przegląd literaturowy ma na celu zbadanie statusu energii odnawialnej w Libii. Takie spojrzenie pozwala uzyskać realistyczny pogląd na ocenę zagadnienia przez społeczeństwo oraz na dostępne w tym zakresie usługi. Wykazano, że niezbędne są dalsze badania w zakresie energii odnawialnej. Aby zrozumieć wyzwania i trudności we wdrażaniu odnawialnych źródeł energii, jakie stoją przed właściwymi organami, przedsiębiorstwami i ich kierownictwem, trzeba szerzej zapoznać się z warunkami funkcjonowania sektora energetycznego w Libii. Wskazuje to na potrzebę przeprowadzenia różnych analiz w celu zbadania wyzwań, głównie finansowych i technologicznych, utrudniających wdrażanie użytkowania energii odnawialnej w Libii. Ponadto, poziom świadomości i kulturowego postrzegania wykorzystania energii odnawialnej są ważnymi uwarunkowaniami, które należy uznać za bariery mające wpływ na wdrażanie energii odnawialnej w różnych częściach świata także w Libii.
\end{abstract}

SŁowA KLUCZOWE: energia alternatywna, wdrażanie energii odnawialnej, bariery i wyzwania 
